\title{
Relevant but Delayed Information in Negotiated Audit Fees
}

\author{
Karl E. Hackenbrack, Nicole Thorne Jenkins, and Mikhail Pevzner
}

\begin{abstract}
SUMMARY: Audit fee negotiations conclude with the signing of an engagement letter, typically the first quarter of the year under audit. Yet investors do not learn the audit fee paid until disclosed in the following year's definitive proxy statement. We conjecture that negotiated audit fees impound auditors' consequential private, client-specific knowledge about "bad news" events investors will learn eventually. We demonstrate that a proxy for the year-to-year change in the negotiated audit fee has an economically meaningful positive association with proxies for public realizations of "bad news" events that occur during the roughly 12-month period between the negotiation of the audit fee and the disclosure of the audit fee paid. Our results suggest that negotiated audit fees contain information meaningful to investors and that if disclosed proximate to the signing of the engagement letter instead of the following year, information asymmetry between managers and investors would be reduced.
\end{abstract}

Keywords: crashes; audit fees; disclosure.

JEL Classifications: G19, D89, M40.

Data Availability: Available from public sources identified in the text.

Karl E. Hackenbrack is an Associate Professor at Vanderbilt University, Nicole Thorne Jenkins is an Associate Professor at the University of Kentucky, and Mikhail Pevzner is an Associate Professor at the University of Baltimore.

We thank Marleen Willekens (editor) and the anonymous reviewers for their helpful comments that significantly improved the paper. We also appreciate the comments received from participants at George Mason University, 2011 American Accounting Association Annual Meeting in Denver, 2011 International Symposium on Auditing Research in Quebec City, Quebec, 2011 Virginia Accounting Research Conference at the Darden School of Business, 2011 Auditing Section Midyear Meeting in Albuquerque, 2010 University of Illinois Symposium on Auditing Research, University of Kentucky, The Ohio State University, University of South Carolina, and the 2010 Washington DC Area Accounting Research Symposium. Special thanks to Amy Hutton, Michael Kimbrough, Bill Kinney, Dick Larsen, Scott Vandervelde, and Liandong Zhang. We acknowledge comments from Karla Johnstone, Keith Jones, Gopal Krishnan, Ariel Markelevich, Suresh Radhakrishnan, and Ryan Wilson. The authors thank Anirudh Jonnavitula for his valuable research assistance. Professor Pevzner gratefully acknowledges special support from the George Mason University Provost Office's Summer Research Grant and George Mason University's Accounting Advisory Council's Summer Research Grant, and acknowledges the assistance of the EY Accounting Chair at the University of Baltimore. Professor Jenkins acknowledges research support from the EY Research Fellowship at the University of Kentucky.

Editor's note: Accepted by Marleen Willekens. 


\section{INTRODUCTION}

I nformation opaqueness occurs. For example, Kothari, Shu, and Wysocki (2009) document that managers withhold bad news from investors up to a certain threshold. When such accumulated bad news reaches a "tipping point," the company experiences an extreme negative stock price return — a crash (Jin and Myers 2006; Hutton, Marcus, and Tehranian 2009; Kim, Li, and Zhang 2011). The revelation of bad news is a shock to investors, but is less likely to surprise a company's auditor because she has access to a broad array of client-specific information well in advance of investors. Auditors are particularly attuned to the changing risk profile of their clients, including changes in idiosyncratic risk, and price audits accordingly. In this paper we investigate the possibility that auditors' pricing of idiosyncratic risk leads public realizations of changes in clients' idiosyncratic risk. We discuss the current corporate audit fee disclosure mandate in the context of our empirical results, noting that accelerating the disclosure of audit fees could result in more timely communication of information buildups that lead to "tipping points."

An auditor's private, client-specific information is impounded in the negotiated audit fee (Hribar, Kravet, and Wilson 2014; Picconi and Reynolds 2013). Her private information affects the negotiated fee in two ways. ${ }^{1}$ First, changes in a client's circumstances are central to estimating the amount and mix of labor needed to complete the engagement. Second, when changes in client conditions cannot be adequately addressed by altering the amount or mix of labor, she price protects by increasing the risk premium component of the audit fee. ${ }^{2}$ The more significant the change in a client's circumstances, the more pronounced the change in the negotiated audit fee. We control for changing client circumstances that precipitate priced changes in the amount and mix of labor, and investigate the relation between a proxy for the priced changes in a client's risk profile and proxies for subsequent public realizations of a buildup of idiosyncratic risk-stock price crashes.

The auditor and client conclude their audit fee negotiation and sign an engagement letter the first quarter of the fiscal year to be audited, typically at the board meeting convened to approve the release of the prior year's earnings (see Figure 1). ${ }^{3}$ The engagement letter is a fixed fee contract. The negotiated audit fee is very sticky and can only be changed in response to significant unexpected changes in the amount or mix of audit team labor, such as work associated with client delays, and only by mutual agreement of the auditor and the client (Hackenbrack and Hogan 2005). Because it is so difficult to alter the fee articulated in the engagement letter, auditors spend a great deal of time, pre-fee negotiation, in consultation with their clients considering the influence of new developments in the literature, client's operations, client's industry, and in the economy. As a result, the negotiated fee impounds a wealth of both public information and private, client-specific information.

Market participants learn the audit fee paid in the first quarter of the fiscal year following the year under audit. ${ }^{4}$ The audit fee paid and disclosed in the definitive proxy statement includes the

1 Pratt and Stice (1994); Simunic and Stein (1996); Morgan and Stocken (1998); Houston, Peters, and Pratt (1999, 2005); Bell, Landsman, and Shakelford (2001); Seetharaman, Gul, and Lynn (2002); Lyon and Maher (2005); Venkataraman, Weber, and Willenborg (2008).

2 For example, no amount of auditing can protect an auditor should the financial viability of a client be threatened by heightened suspicion that ongoing research and development projects are not likely to generate future positive cash flows.

3 Auditing Standard No. 16 (PCAOB 2010, Appendix C) requires that auditors document their understanding of the terms of an engagement in a contract called an engagement letter.

4 As of February 5, 2001, companies are required to disclose fees paid to the incumbent auditor for services (audit and nonaudit) rendered the prior fiscal year in their proxy statement. The fee information is incorporated by reference into Part III of the company's 10-K. Effective for fiscal years ending after December 15, 2003, if the proxy is not filed within 120 days of the company's year-end, the fee disclosure must be separately stated in the company's 10-K. Proxies are governed by Regulation 14a of the General Rules and Regulations promulgated under the SEC Act of 1934. 


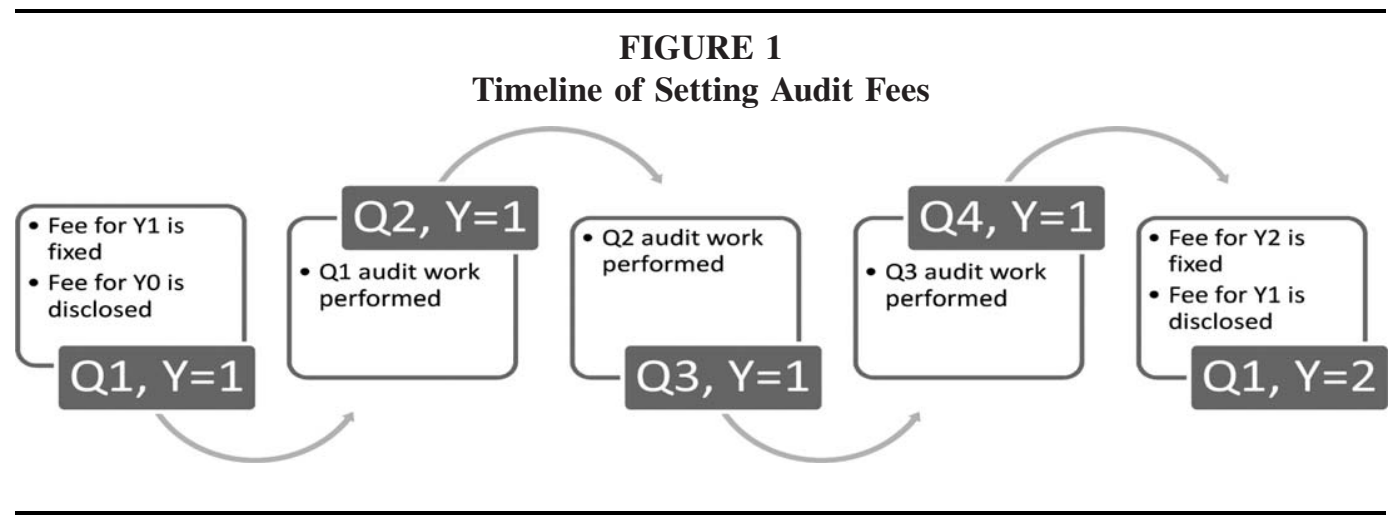

negotiated fixed fee and in rare cases an agreed to supplemental fee for unexpected, clientprecipitated increases in auditor effort. As a result, roughly a year lapses between the auditor-client fee negotiation and investors learning the audit fee paid. Should the negotiated fee reflect the accumulation of the auditor's private knowledge about idiosyncratic risk, then significant changes in the negotiated audit fee might be diagnostic of a fundamental change in the client's risk profile that is not yet publicly known, but economically meaningful to investors.

The year-to-year change in the negotiated audit fee is a measure of company-specific opacity-private, client-specific knowledge, known to management and the auditor when the engagement letter is signed, which is eventually revealed to investors through existing information channels. In our empirical analyses, the year-to-year change in the audit fee paid is adjusted to accommodate/remove supplemental billings, yielding a proxy for the year-to-year change in the negotiated audit fee. We empirically examine the relation between this proxy and stock price crashes that occur over the roughly 12 months between the negotiation of the audit fee and disclosure of the audit fee paid. Stock price crashes represent investors' response to companies reaching a "tipping point" and proxies for the market realization of idiosyncratic risk (Hutton et al. 2009). Should year-to-year changes in our proxy for the negotiated audit fee (company-specific opacity) be related to subsequent stock price crashes (public realization of idiosyncratic risk), then prompt disclosure of the audit fee articulated in the engagement letter would result in more timely communication of the information buildups that lead to "tipping points."

We find, in a large sample of public company annual audits from 2001 through 2011, that our proxy for the change in the negotiated audit fee is positively associated with stock price crashes over the roughly 12 months between the negotiation and the disclosure of the audit fee. In an empirical analysis typical of those used in the extant opacity literature, we document that the year-to-year change in audit fees has significant incremental explanatory power predicting the likelihood of crashes over and above other measures of opacity. In a traditional change specification used in the extant audit fee literature, we find that companies experiencing a stock price crash can, on average, expect their auditor to have negotiated a 2 to 3 percentage point increase in the audit fee in advance of a crash event over and above changes necessitated by operational or structural changes in the client. Consequently, auditors appear to be aware of the buildup of company-specific bad news before a "tipping point" is reached and adjust audit fees accordingly.

Only the audit fee paid is disclosed in the definitive proxy, not the negotiated audit fee. Consequently, we need to establish the veracity of our proxy for changes in the negotiated audit fee; specifically, we need to demonstrate that we effectively control for the atypical cases where the audit fee paid includes a mutually agreed to supplemental fee for client-precipitated events that 
cause unanticipated increases in the amount and/or mix of auditor effort. First, we describe the results of interviews with senior Big 4 audit partners, confirming our understanding of the audit fee negotiation and supplemental billing processes. Second, we identify situations likely to result in supplemental billings, and demonstrate that the pattern of subsequent-year fee revisions differs in an expected way from subsequent-year fee revisions for crash company-years. Third, we demonstrate that changes in audit fees predict crash events that occur during the 12 months after the mandated proxy disclosure of audit fees paid, eliminating completely the need to accommodate supplemental billings. Individually and in aggregate, these robustness tests provide compelling evidence that supplemental billings during the year under audit are not driving our reported results.

Only managers and auditors know the negotiated audit fee articulated in the engagement letter prior to public realizations of the buildup of idiosyncratic risk studied, i.e., "tipping points" over the roughly 12 months between the negotiation and the disclosure of the audit fee. Consequently, company-specific opacity is greater than perhaps necessary and the market is precluded from assimilating timely, consequential information embedded in the negotiated audit fee simply because the current mandate is to disclose audit fee information essentially one year after it is known by insiders. Information-processing costs or lack of timely disclosure mechanisms do not represent barriers to timely disclosure, as the negotiated audit fee is objective, stated in the engagement letter, and is typically known when the definitive proxy statement is filed the first quarter of the year under audit. We do not address in this study how timely disclosure would complicate the auditor-auditee fee negotiation process, or more generally, the auditor-client relationship.

The remainder of the paper proceeds as follows. The second section frames the paper in the extant literature. The third section describes the research design. The fourth section describes the sample selection process and descriptive statistics. The fifth section presents the main results. The sixth section presents robustness tests and additional analysis. The seventh section contains concluding remarks.

\section{PRIOR LITERATURE}

\section{Disclosure and Information Asymmetry}

Both the theoretical and empirical research posit that the more relevant and the higher the quality of information available to shareholders the better. Increased disclosure quality has been theoretically linked to decreases in both information asymmetry and cost of capital, and to an increase in liquidity (Diamond and Verrecchia 1991; Kim and Verrecchia 1994; Lambert, Leuz, and Verrecchia 2007). Empirically, increased disclosure quality has also been linked to increases in liquidity and analyst following (Botosan 1997; Sengupta 1998; Healy and Palepu 2001; Botosan and Plumlee 2002; Lang and Lundholm 1996; Pevzner 2007), and decreases in cost of capital (Frankel, McNichols, and Wilson 1995; Welker 1995; Heflin, Shaw, and Wild 2005; Botosan 1997; Lang and Lundholm 2000; Botosan and Plumlee 2002). These findings are consistent with the notion that greater levels of disclosure quality reduce the risk associated with estimating future cash flows, thus lowering the return demanded by investors. Moreover, increased disclosure quality is thought to decrease information asymmetry by aligning the information that investors have with that of managers. To the extent that the negotiated audit fee impounds client-specific information known to managers but not investors, prompt disclosure of the negotiated audit fee will reduce manager/investor information asymmetry and, consequently, benefit stakeholders.

Information asymmetry is akin to the concept of opacity-lack of transparency. In Jin and Myers's (2006) model, less transparent or equivalently more opaque companies are more likely to experience significant stock price crashes. Their proxy for opacity is the development level of the financial system in the country where a company is domiciled. They find that companies residing in countries with less well-developed financial systems are more likely to experience crashes in their 
stock price. Hutton et al. (2009) also examine the relation between opacity and stock price crashes using earnings management as proxied by discretionary accruals as an indicator of opacity. They find in the pre- but not the post-Sarbanes-Oxley period (2002), companies that engage in earnings management are able to stockpile bad news up to a "tipping point" that, when crossed, results in a stock price crash. Recent work by Kim et al. (2011) shows that tax avoidance is positively related to stock price crash risk, providing additional evidence on the relation between opacity and idiosyncratic risk.

We add to this developing literature by identifying a new source of timely information about changing client circumstances-auditors' accumulated knowledge imbedded in the negotiated audit fee. Our opacity measure is particularly interesting because audit fees are significantly influenced by a third party (an external public accounting firm) that is put at risk by a company's operating results and disclosure choices. Consequently, the negotiated audit fee is a highly credible and objective piece of information.

\section{The Codification of an Auditor's Private Knowledge in the Negotiated Audit Fee}

O'Keefe, Simunic, and Stein (1994) document that hours worked and the labor mix are sensitive to client operations and that audit fees paid are higher for riskier clients. Pratt and Stice (1994) and Johnstone and Bedard (2001) examine how client risk factors affect bid pricing and find that accepted bids contain risk premia for both error and fraud risk after controlling for planned audit hours. These and many other papers are prima facie evidence that auditors utilize their forward-looking, client-specific, private information when negotiating audit fees. Or conversely, that negotiated audit fees impound auditors' client-specific, private information related to changes in the riskiness of a client. Our measure of an auditor's private, client-specific information is the year-to-year change in the audit fee-a proxy for idiosyncratic information known by the auditor but unknown to investors.

By definition, such private client-specific information is not required to be disclosed under Generally Accepted Accounting Principles (GAAP). Further, the AICPA Code of Professional Conduct is clear with regard to the confidentiality of all client information. Therefore, an auditor who is aware of a lawsuit that does not require disclosure, a major customer relationship that is likely to end, a future market expectation that will not be met, or some other circumstance-good or bad - that does not warrant current disclosure under GAAP after adhering to Generally Accepted Audit Standards (GAAS) is compelled to remain silent. Failure to do so violates Rule 301 of the AICPA Code of Professional Conduct (AICPA 1992). ${ }^{5}$ The amount of private information possessed by auditors is vast, which is why independence rules preclude auditors and their immediate family members from investing in audit clients.

Auditors use their client-specific, private information in part to assess their business risk exposure - reputational damage and litigation risk - and per the extant audit literature, in turn, price protect themselves. ${ }^{6}$ The portion of an audit fee increase that is not explained by an increase in audit effort is the risk premium attributed to price protection (Simunic 1980). When the risk that caused the auditor to price protect is learned by the market, the potential loss is now tied to an historical event and future risk premia related to that event are no longer warranted (although fees for

\footnotetext{
5 Evidence of the value of auditor's private information and the requirement not to report this knowledge was recently demonstrated by Scott I. London, a former senior partner with KPMG, who pled guilty to providing Bryan Shaw with inside information regarding at least 14 separate earnings announcements or acquisition by KPMG clients.

6 Pratt and Stice (1994); Simunic and Stein (1996); Morgan and Stocken (1998); Houston et al. (1999, 2005); Barron, Pratt, and Stice (2001); Bell et al. (2001); Seetharaman et al. (2002); Lyon and Maher (2005); Venkataraman et al. (2008); Stanley (2011).
} 
incremental auditor effort associated with the event certainly are). Consequently, price protection by auditors is a reasonable proxy for manager's tendency to conceal bad news from the market.

Several concurrent papers also examine the information contained in audit fees. Hribar et al. (2014) demonstrate the role of unexplained audit fees as a measure of accounting quality by providing evidence that the unexplained portion of audit fees is useful in predicting restatements, fraud, and SEC comment letters. Picconi and Reynolds (2013) investigate the possibility of auditors knowing more than the market by examining the relation between unexplained audit fees and indicators of future performance - operating earnings, the likelihood of delisting, and stock returns. They find that the magnitude of unexplained audit fees is negatively related to future stock performance for small firms. Stanley (2011) provides evidence of an inverse relation between unexplained audit fees and operating performance/solvency. By examining the relationship between stock price crashes and unexplained audit fees, ${ }^{7}$ we look beyond future company performance to the risk profiling ability of information known to insiders but only available to investors with a oneyear lag. That lag creates opacity.

\section{Idiosyncratic Risk in Audit Pricing}

Idiosyncratic risk is the risk that leads to a stock price change due to circumstances that are unique to a specific company, as opposed to the market as a whole. In general, investors can virtually eliminate idiosyncratic risk by forming a diversified portfolio. Such diversification is a challenge for an audit firm because it cannot simply pick and choose clients from the population of companies. Each practice office and individual partner therein have profit and loss responsibility for a portfolio of audit clients that, at that level, is restricted by industry, geography, expertise, existing client base, and so on. Consequently, client acceptance and continuation decisions and fee negotiation are in large part made at the office and partner level (with firm oversight), resulting in service and pricing decisions resembling more of a client-by-client decision-making process than an investor-portfolio approach. As a result, audit-pricing decisions are a function of the labor an auditor anticipates expending to render an opinion and a risk premium that compensates her for idiosyncratic risk.

\section{RESEARCH DESIGN}

\section{Measure of Opacity}

Our measure of opacity is the year-to-year change in the audit fee $\left(\% \Delta\right.$ Fees_Ind $\left.d_{t}\right)$. Specifically, we begin with the annual percentage change in audit fees from year $t$ to $t-1$ divided by the $t-1$ fee. We then median adjust this percentage by industry based on the annual two-digit SIC code to arrive at $\% \Delta$ Fees_Ind ${ }_{t}$. The industry adjustment mitigates the potentially spurious effects of macro changes in audit fees, such as significant industry-specific changes in financial reporting regulations. The source of the audit fee data is the "Revised Audit Fees File" from Audit Analytics (Rosner and Markelevich 2011).

\footnotetext{
7 Our measure of unexplained audit fees is the year-to-year change in the audit fee. Our measure is akin to the abnormal audit fees used in related work (Hribar et al. 2014; Picconi and Reynolds 2013). Those papers estimate a regression model to capture expected audit fees, while we use prior year audit fees as our measure for expected audit fees. Our estimate is more similar to the change in logged audit fees used in Stanley (2011). Like Stanley (2011), a change specification has the virtue of simplicity and does not require that we constrain the structure of the audit fee model to be the same for particular subgroups of companies, such as estimating the audit fee model by year and industry, which introduces measurement error. Rather, we use a random-walk approach and control for expected companyspecific changes within the regression itself.
} 


\section{Measure of Public Realization of Idiosyncratic Risk}

Our measure of realized idiosyncratic risk is stock price crash $(C R A S H)$. Since the audit fee is negotiated in the first quarter of the year under audit and the audit fee paid is disclosed the first quarter of the fiscal year following the year under audit, $C R A S H$ is computed from the end of the first quarter of the year under audit through the end of the first quarter of the following fiscal year. ${ }^{8}$

CRASH is estimated as in Hutton et al. (2009), equaling 1 when $W_{i t}=\log \left(1+u_{i t}\right)$ is more than 3.09 standard deviations below the annual mean for all companies in the same 12-month period, and 0 otherwise. The weekly residual stock return $u_{i t}$ is estimated as follows:

$$
R_{i t}=a_{0}+a_{1} * R_{m, t-2}+a_{2} * R_{m, t-1}+a_{3} * R_{m, t}+a_{4} * R_{m, t+1}+a_{5} * R_{m, t+2}+u_{i t}
$$

where $R_{i t}$ is a company's total raw cumulative weekly stock return for week $t$; and $R_{m, t}$ is the cumulative value-weighted weekly stock return from CRSP (value-weighted return is reported daily and cumulated each week). We require at least 26 weeks of available data to estimate Equation (1).

CRASH is not simply a tweak of traditional measurers of stock price variability, like the standard deviation of returns. A traditional standard deviation of returns measure captures the dispersion of company returns over a 12-month period, whereas $C R A S H$ picks up extreme market movements at a point in time (a week). A company with a low standard deviation of returns can experience a crash event. When we include the control variable SIGMA (the standard deviation of returns) in the audit fee model (untabulated), SIGMA is statistically significant, with CRASH incrementally significant, at the level and significance of our reported results. Consequently, CRASH measures a different aspect of idiosyncratic risk than SIGMA measures.

\section{Baseline Likelihood of CRASH Models}

Our starting point is a faithful rendering of Hutton et al. (2009) wherein $C R A S H$ is regressed on opacity, the three-year sum of the absolute value of annual discretionary accruals (OPAQUE) in a logit model. Adding our measure of opacity $\left(\% \Delta\right.$ Fees_Ind $\left._{t}\right)$ yields the following empirical model:

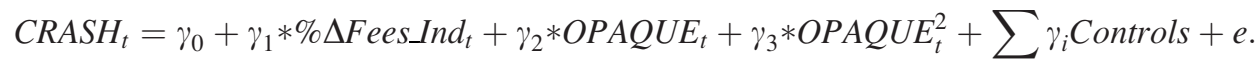

The control variables taken from Hutton et al. (2009) are $R O E_{t}, S I Z E_{t-1}, M T B_{t-1}$, and $L E V_{t-1} \cdot{ }^{9}$ Year and industry fixed effects are also included. $R O E$ is measured as income before extraordinary items divided by the book value of equity. Its coefficient is negative in Hutton et al. (2009), indicating that higher-performing firms have less crash risk. SIZE is the log of market value of equity, and MTB is the market value of equity divided by the book value of equity. Hutton et al. (2009) find that larger firms are more likely to experience crash events, while $M T B$ is not associated with crash risk. $L E V$ is total debt divided by total assets and is associated with lower crash risk, perhaps due to the endogeneity of capital structure choices. Hutton et al. (2009) find in the pre- but not the post-SOX period that the likelihood of a crash event is increasing in OPAQUE and is moderated by OPAQUE ${ }^{2}$.

Next is a faithful rendering of Kim et al. (2011) wherein $C R A S H$ is regressed on opacity, the likelihood that companies participate in tax shelters (SHELTER) (Wilson 2009) in a logit model. Adding our measure of opacity $\left(\% \Delta F e e s_{-} I n d_{t}\right)$ yields the following empirical model:

\footnotetext{
8 The tenor of our results is unaffected by measuring CRASH from end of the first quarter through the end of the fourth quarter of the fiscal year under audit.

9 In keeping with Hutton et al. (2009), the control variables are measured at the beginning of the year, except for ROE, which is measured contemporaneously. The explanation given in Hutton et al. (2009) for using the contemporaneous $R O E$ measure is that accounting researchers typically control for the effect of current period company performance.
} 


$$
\text { CRASH }_{t}=\gamma_{0}+\gamma_{1} * \% \Delta \text { Fees_Ind } t+\gamma_{2} * \text { SHELTER }+\sum \gamma_{t} \text { Controls }_{t}+e .
$$

In addition to the control variables taken from Hutton et al. (2009), we follow Kim et al.'s (2011) lead and include Hutton et al.'s (2009) OPAQUE variable, as well as DTURN $N_{t-1}, N S K E W_{t-1}$, $S I G M A_{t-1}$, and $R E T_{t-1}$. Year and industry fixed effects are also included. DTURN is a proxy for the difference in beliefs between investors and is measured as the de-trended average monthly stock turnover. NSKEW is the negative skewness of weekly returns. SIGMA is the standard deviation of weekly returns. RET is the average of weekly returns. Each of these incremental control variables is positively related to crash risk in Kim et al. (2011). Kim et al. (2011) replace $R O E$ with $R O A_{t-1}$, earnings before extraordinary items divided by total assets. Similar to $R O E$, the coefficient on $R O A$ is negative, consistent with higher-performing companies having a lower probability of a crash event. Kim et al. (2011) find that companies that are more likely to participate in tax shelters have increasing levels of crash risk.

\section{Baseline Audit Fee Model}

We use the ordinary least squares estimation technique to assess the association between $\% \Delta$ Fees_Ind $_{t}$ and CRASH in the following model:

$$
\% \Delta \text { Fees_Ind } t=\gamma_{0}+\gamma_{1} * \text { CRASH } H_{t}+\sum \gamma_{i} \text { Controls }+e .
$$

The control variables in the model proxy for the priced change in the amount or mix of audit labor, effectively decomposing the change in the audit fee into the component associated with the public revelation of increased idiosyncratic risk-CRASH - and that associated with increased audit effort-control variables. The operation-related control variables are included to account for the changes in a company's financial size and makeup that would lead to a change in audit effort or a change in auditor labor mix. The structure-related control variables are designed to minimize the risk that our proxy for the negotiated audit fee includes fees associated with supplemental billings caused by unexpected client-precipitated events that changed the planned scope of the audit.

All control variables are common determinants of audit fees in the extant literature, ${ }^{10}$ and the variables used here are consistent with those used in Ghosh and Pawlewicz (2009). These controls are particularly important for us since they capture the likely increases in audit fees due to higher anticipated effort, which we want to isolate from changes in idiosyncratic risk. Because the model that we are estimating is a change specification, many of the control variables identified in audit fee literature as determinates of the level of audit fees are not relevant, such as auditor tenure.

A client's financial condition significantly affects audit fees (Pratt and Stice 1994). Following Ghosh and Pawlewicz (2009), we include a control for firm size (\% $\%$ ASSETS $\left.t_{-1}\right)$, which is expected to be positively associated with the change in audit fees (Simunic 1980). We control for the concentration in the audit industry using the change in normalized Herfindahl Index $\left(\% \triangle H E R F E N_{t-1}\right)$, which is also expected to be positively associated with the change in audit fees. In addition, we include two sets of proxies: one for audit risk (Simunic 1980; Craswell Francis, and Taylor 1995; Seetharaman et al. 2002), and another for audit complexity (Ghosh and Lustgarten 2006). Audit risk control variables include the change in current assets $\left(\% \Delta C U R R E N T \_A S S E T S_{t-1}\right)$, current ratio $\left(\% \Delta C U R R E N T \_R A T I O_{t-1}\right)$, leverage $\left(\% \Delta L E V_{t-1}\right)$, and

10 Simunic (1980); Craswell et al. (1995); Ashbaugh-Skaife, Lafond, and Mayhew (2003); Whisenant, Sankaraguruswamy, and Raghunandan (2003); Larker and Richardson (2004); Krishnan, Pevzner, and Sengupta (2012) to name a few. 


\section{TABLE 1}

\section{Sample Selection}

\begin{tabular}{|c|c|}
\hline & $\begin{array}{l}\text { Number of } \\
\text { Observations }\end{array}$ \\
\hline $\begin{array}{l}\text { All available annual audit fee data in Audit Analytics for entities that filed either } \\
\text { a } 10 \text {-K or a definitive proxy statement in the period 2000-2011 }\end{array}$ & 110,336 \\
\hline \multicolumn{2}{|l|}{ Loss of a single $\% \Delta F e e s_{t}$ observation } \\
\hline First year that an entity is included in Audit Analytics & $(10,576)$ \\
\hline Auditor change, migration of Arthur Andersen clients & (969) \\
\hline Auditor change, involving a Big 4 firm & $(2,136)$ \\
\hline Auditor change, strictly among non-Big 4 firms & $(8,752)$ \\
\hline \multicolumn{2}{|l|}{ Loss of two $\% \Delta$ Fees $_{t}$ observations } \\
\hline Incomplete audit fee time-series data available in Audit Analytics & $(7,778)$ \\
\hline Two or more auditors for one company in one year & $(1,145)$ \\
\hline Compustat coverage not available & $(21,115)$ \\
\hline Historical SIC code not available in Compustat & $(1,980)$ \\
\hline CRSP coverage not available & $(8,664)$ \\
\hline Financial companies (SIC code $6 \mathrm{XXX}$ ) and regulated utilities (SIC code $49 \mathrm{XX}$ ) & $(13,314)$ \\
\hline Average annual share price less than $\$ 2.50$ & $(5,220)$ \\
\hline Insufficient data to calculate $C R A S H$ & $(979)$ \\
\hline Data available for both $\% \Delta F e e s_{t}$ and $C R A S H$ (Table 3) & 27,708 \\
\hline
\end{tabular}

The sample period spans 2001-2011. All available data from Audit Analytics, Compustat, and CRSP are used. The variables are defined in Appendix A.

profitability $\left(\% \triangle E A R N_{t-1}\right)$. We also include an indicator variable for loss firms $\left(\operatorname{LOSS}_{t}\right)$. The controls for audit complexity are included to explain changes in audit fees due to changes in expected audit effort. The audit complexity control variables include the percentage change in the receivable ratio $\left(\% \triangle A R \_R A T I O_{t-1}\right)$, the inventory ratio $\left(\% \Delta I N V_{-} R A T I O_{t-1}\right)$, income from foreign operations $\left(\% \Delta F G N_{t-1}\right)$, market-to-book ratio $\left(\% \Delta M T B_{t-1}\right)$, special items $\left(\% \triangle S P E C_{t-1}\right)$, and the percentage change in reported segments $\left(\% \Delta S E G M_{t-1}\right)$. In addition, we control for the company's first 404 audit (FIRST404), the issuance of a modified or qualified audit opinion $\left(Q U A L_{t}\right)$, the occurrence of a merger or acquisition during the year $\left(A C Q_{t}\right)$, material internal control weaknesses $\left(W E A K_{t}\right)$, the auditor being a Big 5 auditor (B5), and stock issuances $\left(I S S U E_{t}\right)$.

All continuous variables are winsorized at the 1st and 99th percentiles. Test statistics are estimated using standard errors cluster adjusted on company and fiscal year. Detailed definitions of all variables are presented in Appendix A.

\section{SAMPLE SELECTION AND SUMMARY STATISTICS}

\section{Sample Selection}

The sample selection process is tabulated in Table 1. We begin with all available data in Audit Analytics from 2000 (first year of audit fee coverage) through 2011 for entities that filed either a 10-K or a definitive proxy statement, resulting in 110,336 company-year observations. Needing consecutive years of audit fee data to compute $\% \Delta$ Fees_Ind $t$, the change in audit fees, reduces the sample size by 
22,433-10,576 first year of coverage by Audit Analytics, 969 Arthur Andersen clients moving to a new auditor, and 10,888 auditor changes. These items resulted in one year of lost data. In addition we lost two years of data due to incomplete time-series data for fees $(7,778)$ and when two or more auditors are listed in a particular year for one company $(1,145)$. We eliminated observations for entities not covered by Compustat $(21,115)$ or CRSP $(8,664)$ and entities without SIC codes $(1,980)$. Consistent with the extant literature, we eliminate financial and utilities companies $(13,314)$ as well as companies that have stock prices less than $\$ 2.50(5,220)$. The sample is further reduced due to insufficient data to estimate CRASH (979), resulting in a sample of 27,708 company-year observations with data for the two primary variables, \% $\triangle F e e$ Ind $_{t}$ and $C R A S H$.

\section{Descriptive Statistics}

Table 2 summarizes the descriptive statistics for all variables used in the study. Panel A reports the statistics for the variables of interest. The mean (median) $\% \Delta F e e s$ and $\% \Delta F e e s \_$Ind is 26 percent ( 7 percent) and 15 percent ( 0 percent), respectively. Similar to the Hutton et al. (2009) sample, 23 percent of the sample company-years evidence a crash event. Of the 4,859 companies represented in our sample, 3,231 (66.4 percent) experience a crash event at least once during the sample period. The percentage of observations in our sample that are opaque (OPAQUE) is similar to the Hutton et al. (2009) sample-25 percent versus 24 percent. Companies in our sample are modestly more likely to engage in tax shelters (SHELTER) than those in the Kim et al. (2011) sample-53 percent versus 48 percent.

The control variables from our crash and audit fee models further describe our sample. Panel B of Table 2 reports the control variables for the crash model. The sample firms appear to be glamour firms on average with a $M T B$ of 3.08 and hold debt in excess of 50 percent of their total assets $(L E V)$. On average they produce an $R O A$ of -1.0 percent and $R O E$ of 4 percent. The firms have an average NSKEW of -0.01 indicating that our sample is less crash prone than the Kim et al. (2011) and Hutton et al. (2009) samples. The variance in weekly returns for the sample (SIGMA) is similar to that in Kim et al. (2011) at 0.06 .

Panel C of Table 2 contains the control variables for the audit fee model. Approximately 84 percent of the company-years in our sample were audited by one of the Big 5 firms. Sixty-nine percent of the sample companies (12 percent of our sample company-years) experienced their first 404 audit during the sample period. An internal control weakness (WEAK) was reported for 4 percent of the company-years and an audit opinion other than a clean opinion $(Q U A L)$ for 45 percent. ${ }^{11}$ Acquisitions $(A C Q)$ occurred in 12 percent of the observations and stock issuances (ISSUE) in 6 percent. Approximately 30 percent of the firms in our sample have negative earnings $(L O S S)$. The percentage change in assets $(\% \triangle A S S E T)$, market to book $(\% \triangle M T B)$, leverage $(\% \triangle L E V)$, special items $(\% \triangle S P E C)$, number of reported segments $(\% \triangle S E G M)$, current assets (\% $\%$ CURRENT_ASSETS), current ratio (\% $\%$ CURRENT_RATIO), accounts receivable

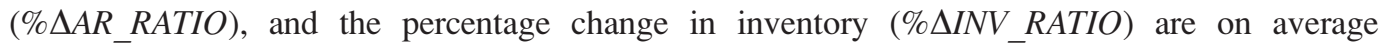
positive, while the change in earnings $(\% \triangle E A R N)$ is on average negative.

\section{Additional Descriptive Statistics}

Table 3 presents additional descriptive statistics for $C R A S H$ and the change in audit fee variables (\% $\%$ Fees and $\% \Delta$ Fees_Ind). Panel A shows that the distribution of crash events by year

11 Between 2001 and 2011, qualified, adverse, and disclaimers together totaled 83 of the audit opinions in Compustat, or 0.08 percent of the total population of audit opinions. Consequently, virtually all of the modified opinions are unqualified opinions with explanatory language. 
TABLE 2

\section{Descriptive Statistics}

Panel A: Variables of Interest

\begin{tabular}{lll} 
Variable & & $\mathbf{n}$ \\
\cline { 1 - 1 }$\%$ Fees $_{t}$ & & 27,708 \\
$\% \Delta$ Fees_Ind $_{t}$ & & 27,708 \\
CRASH & & 27,708 \\
OPAQUE & & 24,199 \\
SHELTER & & 25,978
\end{tabular}

\begin{tabular}{|c|c|c|}
\hline Mean & STD & Q1 \\
\hline 0.26 & 0.69 & -0.06 \\
\hline 0.15 & 0.64 & -0.13 \\
\hline 0.23 & 0.42 & 0.00 \\
\hline 0.25 & 0.28 & 0.10 \\
\hline 0.53 & 0.30 & 0.29 \\
\hline
\end{tabular}

\begin{tabular}{c} 
Median \\
\hline 0.07 \\
0.00 \\
0.00 \\
0.17 \\
0.56
\end{tabular}

$\frac{\mathbf{Q 3}}{0.32}$
0.21
0.00
0.30
0.79

Panel B: Crash Model Control Variables

\begin{tabular}{|c|c|c|c|c|}
\hline Variable & $\mathbf{n}$ & Mean & STD & Q1 \\
\hline$R O E$ & 21,731 & 0.04 & 0.46 & -0.02 \\
\hline$S I Z E_{t-1}$ & 27,159 & 6.28 & 1.82 & 5.02 \\
\hline$M T B_{t-1}$ & 27,159 & 3.08 & 4.47 & 1.32 \\
\hline$L E V_{t-1}$ & 27,465 & 0.56 & 0.37 & 0.31 \\
\hline$D T U R N_{t-1}$ & 26,654 & 0.02 & 0.82 & -0.26 \\
\hline$N S K E W_{t-1}$ & 26,232 & -0.01 & 0.43 & -0.18 \\
\hline$S_{S I G M A_{t-1}}$ & 21,322 & 0.06 & 0.03 & 0.04 \\
\hline$R E T_{t-1}$ & 21,322 & -0.19 & 0.20 & -0.23 \\
\hline$R O A_{t-1}$ & 27,559 & -0.01 & 0.26 & -0.02 \\
\hline
\end{tabular}

\begin{tabular}{|c|c|}
\hline Median & Q3 \\
\hline 0.10 & 0.19 \\
\hline 6.20 & 7.41 \\
\hline 2.16 & 3.68 \\
\hline 0.51 & 0.71 \\
\hline 0.01 & 0.28 \\
\hline-0.02 & 0.13 \\
\hline 0.05 & 0.07 \\
\hline-0.12 & -0.06 \\
\hline 0.04 & 0.09 \\
\hline
\end{tabular}

Panel C: Audit Fee Model Control Variables

\begin{tabular}{|c|}
\hline Variable \\
\hline FIRST404 \\
\hline$A C Q$ \\
\hline ISSUE \\
\hline WEAK \\
\hline$Q U A L$ \\
\hline$\% \triangle A S S E T_{t-1}$ \\
\hline$\% \triangle E A R N_{t-1}$ \\
\hline$\% \Delta F G N_{t-1}$ \\
\hline$\% \Delta M T B_{t-1}$ \\
\hline$\% \Delta L E V_{t-1}$ \\
\hline$\% \triangle S P E C_{t-1}$ \\
\hline$\% \Delta S E G M_{t-1}$ \\
\hline BIG5 \\
\hline$\% \triangle H E R F E N_{t-1}$ \\
\hline$\% \triangle C U R R E N T$ ASSETS $_{t-1}$ \\
\hline$\% \triangle C U R R E N T$ RATIO ${ }_{t-1}$ \\
\hline$\% \triangle A R \_R A T I O_{t-1}$ \\
\hline $\begin{array}{l}\% \Delta I N \bar{V}{ }_{-} R A T I O_{t-1} \\
\text { LOSS }\end{array}$ \\
\hline
\end{tabular}

\begin{tabular}{|c|c|c|c|}
\hline n & Mean & STD & Q1 \\
\hline 27,708 & 0.12 & 0.32 & 0.00 \\
\hline 27,708 & 0.12 & 0.33 & 0.00 \\
\hline 27,708 & 0.06 & 0.24 & 0.00 \\
\hline 27,708 & 0.04 & 0.20 & 0.00 \\
\hline 27,698 & 0.45 & 0.50 & 0.00 \\
\hline 27,569 & 0.23 & 0.65 & -0.03 \\
\hline 27,533 & -0.12 & 3.78 & -0.69 \\
\hline 27,572 & 0.00 & 1.43 & 0.00 \\
\hline 26,004 & 0.13 & 0.93 & -0.29 \\
\hline 27,445 & 0.25 & 0.81 & -0.07 \\
\hline 27,572 & 0.27 & 6.73 & -1.00 \\
\hline 27,427 & 0.01 & 0.29 & 0.00 \\
\hline 27,708 & 0.84 & 0.36 & 1.00 \\
\hline 27,561 & 0.02 & 0.10 & -0.03 \\
\hline 26,934 & 0.02 & 0.24 & -0.07 \\
\hline 26,930 & 0.12 & 0.62 & -0.15 \\
\hline 27,421 & 0.06 & 0.50 & -0.14 \\
\hline 27,298 & 0.03 & 0.33 & -0.09 \\
\hline 27,708 & 0.30 & 0.46 & 0.00 \\
\hline
\end{tabular}

\begin{tabular}{|c|c|}
\hline Median & Q3 \\
\hline 0.00 & 0.00 \\
\hline 0.00 & 0.00 \\
\hline 0.00 & 0.00 \\
\hline 0.00 & 0.00 \\
\hline 0.00 & 1.00 \\
\hline 0.07 & 0.22 \\
\hline 0.00 & 0.46 \\
\hline 0.00 & 0.00 \\
\hline-0.02 & 0.31 \\
\hline 0.05 & 0.26 \\
\hline-0.57 & 0.00 \\
\hline 0.00 & 0.00 \\
\hline 1.00 & 1.00 \\
\hline 0.00 & 0.05 \\
\hline 0.01 & 0.09 \\
\hline 0.01 & 0.20 \\
\hline 0.00 & 0.14 \\
\hline 0.00 & 0.08 \\
\hline 0.00 & 1.00 \\
\hline
\end{tabular}

Descriptive statistics cover the 27,708 observations from the sample period 2001 to 2011 . The sample selection process is described in Table 1.

All variables are defined in Appendix A. 
TABLE 3

Additional Descriptive Statistics for CRASH and Percentage Change in Audit Fees

Panel A: Distribution of Companies with at Least One CRASH Event versus the Distribution of Sample Observations by Year

\begin{tabular}{|c|c|c|c|c|}
\hline Year & $\begin{array}{l}\text { Observations with at } \\
\text { Least One } C R A S H\end{array}$ & Percent of Total & All Observations & Percent of Total \\
\hline 2001 & 336 & $5.22 \%$ & 1,838 & $6.63 \%$ \\
\hline 2002 & 576 & $8.95 \%$ & 2,270 & $8.19 \%$ \\
\hline 2003 & 526 & $8.18 \%$ & 2,662 & $9.61 \%$ \\
\hline 2004 & 700 & $10.88 \%$ & 2,950 & $10.65 \%$ \\
\hline 2005 & 753 & $11.71 \%$ & 2,823 & $10.19 \%$ \\
\hline 2006 & 722 & $11.22 \%$ & 2,820 & $10.18 \%$ \\
\hline 2007 & 699 & $10.87 \%$ & 2,809 & $10.14 \%$ \\
\hline 2008 & 690 & $10.73 \%$ & 2,569 & $9.27 \%$ \\
\hline 2009 & 410 & $6.37 \%$ & 2,279 & $8.23 \%$ \\
\hline 2010 & 470 & $7.31 \%$ & 2,339 & $8.44 \%$ \\
\hline 2011 & 551 & $8.57 \%$ & 2,349 & $8.48 \%$ \\
\hline Total & 6,433 & & 27,708 & \\
\hline
\end{tabular}

Panel B: Distribution of Companies with at Least One CRASH Event versus the Distribution of Sample Observations by Industry

\begin{tabular}{|c|c|c|c|c|c|}
\hline $\begin{array}{l}\text { Two-Digit } \\
\text { SIC Code }\end{array}$ & Industry & $\begin{array}{c}\text { Observations } \\
\text { with at Least } \\
\text { One } C R A S H\end{array}$ & $\begin{array}{c}\text { Percent of } \\
\text { Total }\end{array}$ & $\begin{array}{c}\text { All } \\
\text { Obs. }\end{array}$ & $\begin{array}{l}\text { Percent } \\
\text { of Total }\end{array}$ \\
\hline 28 & Chemicals and Allied Products & 795 & $12.36 \%$ & 3,081 & $11.12 \%$ \\
\hline 35 & Industrial Machinery \& Equipment & 427 & $6.64 \%$ & 1,886 & $6.81 \%$ \\
\hline 36 & Electronic \& Other Electric Equipment & 594 & $9.23 \%$ & 2,617 & $9.44 \%$ \\
\hline 38 & Instruments Related Products & 549 & $8.53 \%$ & 2,157 & $7.78 \%$ \\
\hline \multirow[t]{2}{*}{73} & Business Services & 985 & $15.31 \%$ & 3,716 & $13.41 \%$ \\
\hline & Other Industries & 3,083 & $47.93 \%$ & 14,251 & $51.44 \%$ \\
\hline Total & & 6,433 & $100.00 \%$ & 27,708 & $100.00 \%$ \\
\hline
\end{tabular}

Panel C: Distribution of Unadjusted and Industry-Adjusted Percentage Change in Audit Fee by Year

\begin{tabular}{|c|c|c|c|c|c|}
\hline \multirow[b]{2}{*}{ Year } & \multirow{2}{*}{$\begin{array}{l}\text { Number of } \\
\text { Observations }\end{array}$} & \multicolumn{2}{|c|}{$\% \Delta$ Feest } & \multicolumn{2}{|c|}{$\% \Delta$ Fees_Ind } \\
\hline & & Mean & Median & Mean & Median \\
\hline 2001 & 1,838 & 0.20 & 0.10 & 0.11 & 0.01 \\
\hline 2002 & 2,270 & 0.28 & 0.19 & 0.13 & 0.03 \\
\hline 2003 & 2,662 & 0.32 & 0.19 & 0.16 & 0.03 \\
\hline 2004 & 2,950 & 0.91 & 0.62 & 0.49 & 0.18 \\
\hline 2005 & 2,823 & 0.51 & 0.15 & 0.32 & 0.00 \\
\hline 2006 & 2,820 & 0.20 & 0.07 & 0.12 & -0.01 \\
\hline 2007 & 2,809 & 0.16 & 0.04 & 0.10 & -0.01 \\
\hline 2008 & 2,569 & 0.06 & 0.02 & 0.04 & 0.00 \\
\hline 2009 & 2,279 & -0.03 & -0.04 & 0.01 & 0.00 \\
\hline
\end{tabular}


TABLE 3 (continued)

\begin{tabular}{|c|c|c|c|c|c|}
\hline \multirow[b]{2}{*}{ Year } & \multirow{2}{*}{$\begin{array}{c}\text { Number of } \\
\text { Observations }\end{array}$} & \multicolumn{2}{|c|}{$\% \Delta$ Fees $_{t}$} & \multicolumn{2}{|c|}{$\% \Delta$ Fees_Ind ${ }_{t}$} \\
\hline & & Mean & Median & Mean & Median \\
\hline 2010 & 2,339 & 0.02 & -0.01 & 0.02 & 0.00 \\
\hline 2011 & 2,349 & 0.08 & 0.02 & 0.05 & 0.00 \\
\hline
\end{tabular}

Total

27,708

Descriptive statistics cover the 27,708 observations from sample period 2001 to 2011 . The sample selection process is described in Table 1.

All variables are defined in Appendix A.

mimics the distribution of sample observations by year, with the percentage of companies experiencing a crash event ranging from a low of 5 percent in 2001 to a high of 11 percent in the mid-2000s. Panel B reveals that crash events occur most often in the Business Services-7300 (15 percent) and Chemical and Allied Products-2800 (12 percent) industries, consistent with their representation in the sample (13 percent and 11 percent, respectively) and the Audit Analytics database prior to sample construction. The crash model includes industry fixed effects and the dependent variable in the fee model has been industry adjusted.

Panel $\mathrm{C}$ of Table 3 presents descriptive statistics for measures of percentage change in audit fees by year, both with (\% $\%$ Fees_Ind) and without $(\% \Delta F e e s)$ the industry adjustment. Both measures behave similarly through the sample period, generally increasing, with the most pronounced increases in 2004 and 2005. This pattern is consistent with auditor efforts related to the implementation of Sarbanes-Oxley Section 404. The significant slowing in 2008 and beyond is likely due to the recession and growing comfort with 404-related work. Our empirical models include year fixed effects to control for economy-wide effects, and the audit fee model includes a control variable for the first-time adoption of Sarbanes-Oxley Section 404 (FIRST404). The tenor of our results is unaffected by replacing the industry adjusted percentage change in audit fees $\left(\% \Delta F e e s_{-} I n d\right)$ with the unadjusted percentage change in audit fees $(\% \Delta F e e s)$.

\section{Correlation Coefficients}

Table 4 summarizes the Pearson (bottom left) and the Spearman's rank (top right) correlation coefficients among select variables used in the study. Audit fees increase the first year of a 404 audit $(\mathrm{r}=0.38$ and 0.34 for Pearson and Spearman's, respectively; FIRST404 and \% $\%$ Fees_Ind). Companies with reported losses are less likely to utilize tax shelters $(\mathrm{r}=-0.35$ and -0.32 for Pearson and Spearman's, respectively; SHELTER and LOSS). These relationships are not a surprise. All of the other correlations reported in Table 4 are less than 0.30 and, consequently, not considered a source of multicollinearity. \% $\triangle$ Fees_Ind is positively correlated with CRASH, providing preliminary evidence of the relation between changes in audit fees and our proxy for public revelations of idiosyncratic risk. CRASH is not correlated with OPAQUE, consistent with the correlation results reported in both Hutton et al. (2009) and Kim et al. (2011). Consistent with Kim et al. (2011), SHELTER is not correlated with CRASH and is negatively correlated with OPAQUE. $\% \triangle F e e s$ Ind is positively correlated with OPAQUE, indicating that companies with greater earnings management have increasing audit fees. These univariate relations are further investigated in the multivariate regressions. 


\section{TABLE 4}

\section{Correlation Coefficients}

\begin{tabular}{|c|c|c|c|c|c|c|c|c|c|c|c|}
\hline & 1 & 2 & 3 & 4 & 5 & 6 & 7 & 8 & 9 & 10 & 11 \\
\hline & & & & & & $9 *$ & $-0 .($ & $10 *$ & & 0 & 0 \\
\hline$C R$ & $0.02 *$ & & & & & & & & & & \\
\hline FII & & & & & & & & & & & \\
\hline . $A$ & & & & - & 0.0 & & & & & & \\
\hline$I$ & & -0.0 & 0.0 & $0.03 *$ & - & -0.01 & -0. & 0.0 & -0.01 & -0 . & $10^{*}$ \\
\hline$V$ & & & & & -0.01 & - & $0.06^{*}$ & $0.02 *$ & $0.06^{*}$ & $2 *$ & \\
\hline$Q U$ & -0.0 & & -0. & & -0 & $0.06^{*}$ & - & $-0.03 *$ & 0.01 & -0 . & \\
\hline$\% \triangle A S S E T_{t-1}$ & & & & $0.05^{*}$ & $0.03 *$ & $0.02 *$ & $-0.06^{*}$ & - & $-0.17 *$ & $0.04 *$ & $0.22 *$ \\
\hline LOSS & & $0.02 *$ & $-0.03 *$ & $-0.03 *$ & -0.01 & $0.05^{*}$ & 0.0 & & - & $0.23^{*}$ & $-0.32 *$ \\
\hline & $0.02 *$ & & & 0.00 & $-0.02 *$ & $0.01 *$ & $-0.04 *$ & $0.19 *$ & $0.24 *$ & - & $-0.26^{*}$ \\
\hline SHELTER & -0.00 & $0.03 *$ & $0.02 *$ & $0.04 *$ & $0.09 *$ & $-0.01^{*}$ & $0.13^{*}$ & $0.02 *$ & $-0.35^{*}$ & $-0.08 *$ & - \\
\hline
\end{tabular}

* Denotes two-tailed significance levels at 0.05 .

Pearson (bottom left) and Spearman's rank (top right) correlation coefficients for key variables over the sample period 2001 to 2011 using all available data, 23,520 company-year observations.

All variables are defined in Appendix A.

\section{EMPIRICAL RESULTS}

\section{Crash Models}

In keeping with the prior literature on stock price crashes, we estimate the logit regressions described in Equations (2a) and ( $2 b$ ) and a pooling of the two. The three models are reported in Table 5. Model 1 is the Hutton et al. (2009) model augmented with \% $\Delta$ Fees Ind (Equation (2a)). As in Hutton et al. (2009), the coefficient on their proxy for opacity, OPAQUE, is significantly positive at 0.52 (p-value $<0.001)$ and $O P A Q U E^{2}$ is significantly negative at -0.34 (p-value $<$ 0.001). \% $\triangle$ Fees_Ind, our proxy for opacity, is significantly positive at 0.08 (p-value $<0.001$ ). The coefficients on ROE and SIZE are significant and in the same direction as they are in Hutton et al. (2009). However, the coefficients on $M T B$ and $L E V$ are insignificantly different from 0 . The ability of the $\% \triangle F e e s$ Ind to explain future crash events is significant above and beyond OPAQUE.

Model 2 of Table 5 is the Kim et al. (2011) model augmented with \% $\Delta$ Fees_Ind (Equation (2b)). The coefficient on Kim et al.'s (2011) proxy for opacity, SHELTER, is significantly positive at 0.31 (p-value $<0.001$ ). \% $\Delta$ Fees_Ind, our proxy for opacity, is also significantly positive at 0.09 (p-value < 0.001). The coefficients on SIGMA and RET are significantly positive consistent with Kim et al. (2011). SIZE, MTB, LEV, DTURN, NSKEW, and ROA are insignificantly different from 0 . DTURN, $L E V$, and $R O A$ are weakly or insignificantly different from 0 in Kim et al. (2011). Similar to the findings for Equation (2a), \% $\Delta$ Fees_Ind continues to have explanatory power above and beyond prior measures of opacity, in this case SHELTER.

Last, we combine Equations (2a) and (2b) into Model 3 to determine the explanatory power of $\% \triangle F e e s$ Ind when both OPAQUE and SHELTER and the full menu of control variables are in the same specification. Similar to the findings for Models 1 and 2, the coefficient on $\% \triangle F e e s_{-}$Ind (0.08; p-value < 0.001), OPAQUE (0.46; p-value < 0.001), and SHELTER $(0.32 \mathrm{p}$-value < 0.001$)$ are significantly positive, while the coefficient on $O P A Q U E^{2}$ is significantly negative $(-0.27$; $\mathrm{p}$ value $<0.05)$. Thus, the ability of $\% \Delta F e e s_{-}$Ind to incrementally predict crash events suggests it captures a unique manifestation of opacity relative to OPAQUE and SHELTER. 


\section{TABLE 5}

\section{Crash Model}

$$
\begin{aligned}
& \text { CRASH } H_{t}=\gamma_{0}+\gamma_{1} * \% \Delta \text { Fees_Ind } t_{t}+\gamma_{2} * O P A Q U E_{t}+\gamma_{3} * O P A Q U E_{t}^{2}+\sum \gamma_{i} \text { Controls }+e . \\
& \text { CRASH }_{t}=\gamma_{0}+\gamma_{1} * \% \Delta \text { Fees_Ind } t+\gamma_{2} * \text { SHELTER }_{t}+\sum \gamma_{i} \text { Controls }+e . \\
& \text { CRASH }_{t}=\gamma_{0}+\gamma_{1} * \% \Delta \text { Fees_Ind } t+\gamma_{2} * O P A Q U E_{t}+\gamma_{3} * O P A Q U E_{t}^{2}+\gamma_{4} * \text { SHELTER }_{t} \\
& +\sum \gamma_{i} \text { Controls }+e \text {. }
\end{aligned}
$$

Model 1

\begin{tabular}{crr}
\hline $\begin{array}{c}\text { Coefficient } \\
\text { Estimate }\end{array}$ & & t-stat \\
\cline { 1 - 1 } $0.08^{* * * *}$ & & $(3.97)$ \\
$0.52^{* * * *}$ & & $(2.61)$ \\
$-0.34^{* * * *}$ & & $(-2.59)$ \\
& \\
$-0.09^{*}$ & & $(-1.80)$ \\
$0.05^{* * *}$ & & $(2.97)$ \\
0.00 & & $(0.33)$ \\
0.06 & & $(1.00)$
\end{tabular}

$D_{T U R N_{t-1}}$

$N S K E W_{t-1}$

$R E T_{t-1}$

$S I G M A_{t-1}$

$R O A_{t-1}$

Intercept

Year fixed effects

Industry fixed effects

n

Pseudo $\mathrm{R}^{2}$
Model 2

\begin{tabular}{ccc}
\hline $\begin{array}{c}\text { Coefficient } \\
\text { Estimate }\end{array}$ & & t-stat \\
\cline { 1 - 1 } $0.09^{* * *}$ & & $(4.77)$ \\
& & \\
& \\
$0.31^{* * *}$ & & $(3.02)$ \\
& & \\
0.01 & & $(0.77)$ \\
0.00 & & $(0.97)$ \\
0.08 & & $(1.41)$ \\
0.04 & & $(1.57)$ \\
0.06 & & $(1.31)$ \\
$1.63 * * *$ & & $(4.07)$ \\
$14.06^{* * *}$ & & $(4.61)$ \\
0.17 & & $(1.63)$ \\
$-2.79 * * *$ & & $(-7.04)$ \\
Yes & \\
Yes & \\
20,528 & \\
0.02 &
\end{tabular}

Model 3

\begin{tabular}{crr}
\hline $\begin{array}{c}\text { Coefficient } \\
\text { Estimate }\end{array}$ & & t-stat \\
\cline { 1 - 1 } $0.08^{* * *}$ & & $(4.01)$ \\
$0.46^{* * *}$ & & $(2.49)$ \\
$-0.27^{* *}$ & & $(-2.10)$ \\
$0.32^{* * *}$ & & $(2.61)$ \\
$-0.13^{* * *}$ & & $(-2.58)$ \\
0.02 & & $(0.84)$ \\
0.00 & & $(0.51)$ \\
0.05 & & $(0.82)$ \\
$0.06^{* *}$ & & $(2.20)$ \\
0.05 & & $(0.97)$ \\
$1.36^{* * *}$ & & $(3.20)$ \\
$11.36^{* * *}$ & & $(3.52)$ \\
$0.34^{* * *}$ & & $(2.61)$ \\
$-2.75^{* * *}$ & & $(-5.23)$ \\
Yes & \\
Yes & \\
19,111 & \\
0.02 &
\end{tabular}

$*, * *, * * *$ Denote two-tailed significance levels at $0.1,0.05$, and 0.01 , respectively.

Reported t-statistics are estimated using standard errors clustered on year and firm. All continuous variables are winsorized at the 1st and 99th percentiles. This table presents logistic regression models of CRASH determinants. All variables are defined in Appendix A.

In response to the increased idiosyncratic risk, auditors are either increasing their planned audit work, price protecting against an increase in perceived idiosyncratic risk, or both. The analysis presented in the "Audit Fee Model" section attempts to unravel these two explanations for increasing audit fees in advance of crash events.

\section{Audit Fee Model}

In this section, we estimate Equation (3), which describes the auditor's pricing of their private, client-specific information proxied for with $\% \Delta$ Fees_Ind. This analysis decomposes the drivers of 


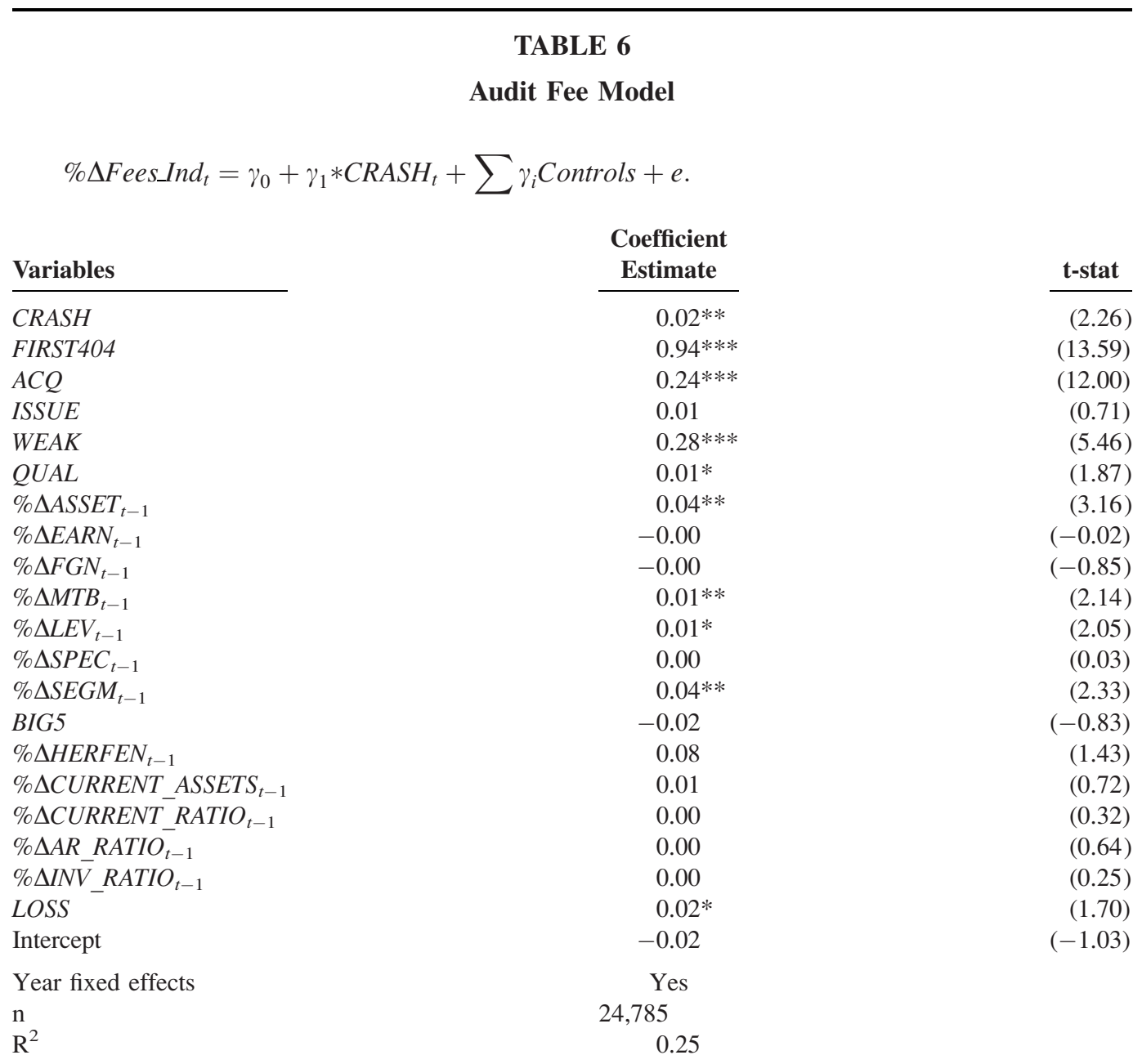

$*, * *, * * *$ Denote two-tailed significance levels at $0.1,0.05$, and 0.01 , respectively.

Reported t-statistics are estimated using standard errors clustered on year and firm. All continuous variables are winsorized at the $1 \mathrm{st}$ and 99 th percentiles. This table presents ordinary least squares models of $\% \Delta F e e s_{-}$Ind $_{t}$ determinants.

All variables are defined in Appendix A.

increased audit fees into the components associated with increased idiosyncratic risk $(C R A S H)$ and increased audit work (control variables). Table 6 is the Ghosh and Pawlewicz (2009) model augmented with $C R A S H$. We find that after controlling for audit risk and audit complexity, the coefficient on $C R A S H$ is significantly positive at 2 percent ( $\mathrm{p}$-value $<0.05$ ). This indicates that, on average, companies experience a 2 percent increase in their audit fees in advance of a stock price crash occurring. These results suggest that a significant portion of the mean increase in audit fees is related to an increase in the auditor's perception of idiosyncratic risk (the mean univariate change in audit fees across the sample period is 15 percent; see Table 2, Panel A).

The pattern of coefficients on the control variables that measures the increase in audit workload or labor mix is as expected. Fees appear to increase when there is an increase in the market-to-book 
ratio, number of segments, and their current assets. Not surprising, companies in our sample experience an increase in their audit fees in the year of their first 404 audit and when there is a material weakness or a qualified audit opinion. Increasing fees also occur when companies have an acquisition. These events might trigger supplemental audit fee billings. Controlling for such events - events that are likely to require auditor effort not anticipated when the audit fee was negotiated-is necessary to ensure that such drivers of changes in audit fees are not assigned to a crash event.

Taken together, the results reported in Tables 5 and 6 are consistent-auditors recognize increases in idiosyncratic risk and respond by engaging in a form of price protection, increasing the audit fee over and above that which is related to increases in audit effort.

\section{ADDITIONAL ANALYSIS AND ROBUSTNESS TESTS}

\section{Reasonableness of the Negotiated Audit Fee Proxy}

In this subsection, we provide evidence that our proxy for the negotiated audit fee is reasonable. We found no academic or professional articles since Palmrose (1989) and Copley and Doucet (1993) that document the contract type used in public company audits, let alone during our sample period. ${ }^{12}$ To avoid relying on common knowledge, we conducted formal interviews with five senior audit partners from three of the Big 4 public accounting firms, each responsible for negotiating audit fees with public companies. In short, all audit partners unequivocally stated audit fees paid rarely deviate from the negotiated audit fee. The audit partners concurred with the description of the fee negotiation process used throughout this paper and stated unanimously and unambiguously their inability to increase negotiated fees unless the audit firm and client agree to supplement the negotiated fee for unexpected, client-necessitated cost overruns-additional audit work must be performed by the firm. The partners indicated an aversion to being viewed as trying to "milk" their clients for additional fees and, therefore, they employ a general practice of avoiding renegotiation of the audit fee for fear of jeopardizing the multi-year client relationship. This perspective is consistent with Hackenbrack and Hogan's (2005) result that realization rates are significantly lower on engagements marred by client imposed delays, i.e., it is hard for firms to pass on unexpected costs. Thus, the audit fee negotiated in the first quarter of the year under audit and documented in the engagement letter is in most cases, de facto, disclosed as the audit fee paid retrospectively in the following year definitive proxy statement, making the audit fee paid in most cases a reasonable proxy for the negotiated audit fee.

\section{Pre- verses Post-SOX Years}

Hutton et al. (2009) find that the ability of abnormal accruals to predict crash events dissipates after the adoption of the Sarbanes-Oxley Act of 2002. This is not the case for our measure of opacity, \% $\%$ Fees_Ind. Consistent with the pattern of audit fee increases observed in Table 3, Panel $\mathrm{C}$, we defined an indicator variable SOX that equals 1 for years after 2005, and 0 otherwise. We then added to the baseline crash model the indicator variable $S O X$ and the interaction term $\% \Delta$ Fees_Ind $*$ SOX. The main effect on \% Panel A (0.08; p-value < 0.02) and the coefficient on $\% \Delta F e e s \_I n d * S O X$ is not significant ( $\mathrm{p}$ value $=0.87$ ). Thus, the ability of audit fee changes to predict crash events is invariant to the adoption of Sarbanes-Oxley.

12 The most recent academic work on fee structure is the Palmrose (1989) analysis of circa 1980 audits where both fixed-fee and cost-plus contracts were observed. Copley and Doucet (1993) find that 79 percent of 1985 external governmental audits were fixed-fee contracts. 


\section{Demise of Arthur Andersen}

During our sample period, Arthur Andersen, one of the Big N auditing firms failed. Chaney and Philipich (2002) and Krishnamurthy, J. Zhou, and N. Zhou (2006) provide evidence that Arthur Andersen clients experienced significant reputational losses that were manifested in stock price declines. In addition, Krishnan (2005) indicates that clients of the Houston office of Arthur Andersen were systematically less conservative in their accounting choices, which could make them more susceptible to stock price crashes. We reexamine our analyses excluding the Arthur Andersen clients prior to their demise and find that the tenor of our results is not affected.

\section{CONCLUSION}

Market participants learn the audit fee paid retrospectively in the first quarter of the fiscal year following the year audited. As a result, roughly a year lapses between the auditor and the client agreeing to the audit fee and investors learning of the audit fee. Audit fees for the year under audit contain potentially valuable information about company-specific risks. We empirically examine the relation between a proxy for the priced changes in a client's risk profile and proxies for subsequent public realizations of idiosyncratic risk, a stock price crash. Our analysis addresses whether changes in audit fees lead public realizations of idiosyncratic risk and, consequently, the question of whether timely disclosure of the audit fee documented in the engagement letter would decrease the level of company-specific opacity, thereby reducing the buildup of undisclosed bad news that leads to "tipping points."

First, we demonstrate that change in audit fees is a proxy for opacity over and above the proxies for level of earnings management and use of tax shelters that have previously been documented in the literature. Second, we find that our proxy for the change in the negotiated audit fee is positively associated with proxies for public realizations of idiosyncratic risk over the, roughly, 12 months between the negotiation and disclosure of the audit fee. After controlling for operational and structural client changes generally associated with increases in auditor effort, we find that companies experiencing a stock price crash can, on average, expect its auditor to have negotiated a 2 to 3 percentage point increase in the industry-adjusted audit fee in advance of a crash event over and above a fee increase necessitated by operational or structural changes in the client. Thus, auditors appear to appreciate and price changes in clients' idiosyncratic risk before investors learn of such changes at informational "tipping points." This result holds for several alternative measures, additional control variables, and model specifications. Moreover, this result holds both before and after SOX implementation, is insensitive to the inclusion of Arthur Andersen clients, and is not driven by supplemental billings.

Company-specific opacity is greater than perhaps necessary as a result of the timing of the audit fee disclosure. Our results suggest that accelerating the mandated corporate disclosure of the audit fee would provide useful information to investors, reducing the severity of negative market reactions when companies announce bad news. Lack of prompt disclosure cannot be attributed to the fee information not being available or the absence of a vehicle through which the information can be disclosed. The negotiated audit fee is objective, stated in the engagement letter, and known when the definitive proxy statement is filed the first quarter of the year under audit. Our empirical findings are a first step in documenting the economically relevant information contained in negotiated fees and demonstrating that auditors price protect in response to their understanding of the risks and rewards their clients face. The analysis does not address the trade-offs between the economic benefits documented and the potential costs, like making a currently cooperative negotiation process more contentious. Future work is needed to better understand these trade-offs. 


\section{REFERENCES}

American Institute of Certified Public Accountants (AICPA). 1992. Confidential Client Information. ET Section 301. Available at: http://www.aicpa.org/Research/Standards/CodeofConduct/Pages/et_300. aspx

Ashbaugh-Skaife, H., R. LaFond, and B. Mayhew. 2003. Do non-audit services compromise auditor independence? Further evidence. The Accounting Review 78 (3): 611-639.

Barron, O., J. Pratt, and J. D. Stice. 2001. Misstatement direction, litigation risk, and planned audit investment. Journal of Accounting Research 39 (3): 449-462.

Bell, T., W. Landsman, and D. Shakelford. 2001. Auditors' perceived business risk and audit fees: Analysis and evidence. Journal of Accounting Research 39 (1): 35-43.

Botosan, C. 1997. Disclosure level and the cost of equity capital. The Accounting Review 72 (3): 323-349.

Botosan, C., and M. Plumlee. 2002. A re-examination of disclosure level and the expected cost of equity capital. Journal of Accounting Research 40 (1): 21-40.

Chaney, P., and K. Philipich. 2002. Shredded reputation: The cost of audit failure. Journal of Accounting Research 40 (4): 1221-1245.

Chen, J., H. Hong, and J. Stein. 2001. Forecasting crashes: Trading volume, past returns, and conditional skewness in stock prices. Journal of Financial Economics 61: 345-381.

Copley, P. A., and M. S. Doucet. 1993. Auditor tenure, fixed fee contracts, and the supply of substandard single audits. Public Budgeting \& Finance 13 (3): 23-35.

Craswell, A. T., J. R. Francis, and S. L. Taylor. 1995. Auditor brand name reputations and industry specialization. Journal of Accounting \& Economics 20 (3): 297-322.

Diamond, D., and R. Verrecchia. 1991. Disclosure, liquidity, and cost of capital. Journal of Finance 46 (4): $1325-1359$.

Frankel, R., M. McNichols, and P. Wilson. 1995. Discretionary disclosure and external financing. The Accounting Review 70 (1): 135-150.

Ghosh, A., and R. Pawlewicz. 2009. The impact of regulation on auditor fees: Evidence from the SarbanesOxley Act. Auditing: Journal of Practice \& Theory 28 (2): 171-197.

Ghosh, A., and S. Lustgarten. 2006. Pricing of initial audit engagements by large and small audit firms. Contemporary Accounting Research 23 (2): 333-368.

Hackenbrack, K., and C. Hogan. 2005. Client retention and engagement-level pricing. Auditing: Journal of Practice \& Theory 24 (1): 7-20.

Healy, P., and C. Palepu. 2001. Information asymmetry, corporate disclosure, and capital markets. Journal of Accounting \& Economics 31: 405-440.

Heflin, F., K. Shaw, and J. Wild. 2005. Disclosure quality and market liquidity: The effect of depth quotes and order sizes. Contemporary Accounting Research 22 (4): 829-865.

Houston, R., M. Peters, and J. Pratt. 1999. The audit risk model, business risk, and audit-planning decisions. The Accounting Review 74 (3): 281-298.

Houston, R., M. Peters, and J. Pratt. 2005. Nonlitigation risk and pricing of audit services. Auditing: A Journal of Practice \& Theory 24 (1): 37-53.

Hribar, P., T. Kravet, and R. Wilson. 2014. A new measure of accounting quality. Review of Accounting Studies 19: 506-538.

Hutton, A., A. J. Marcus, and H. Tehranian. 2009. Opaque financial reports, $\mathrm{R}^{2}$, and crash risk. Journal of Financial Economics 94: 67-86.

Jin, L., and S. C. Myers. 2006. $\mathrm{R}^{2}$ around the world: New theory and new tests. Journal of Financial Economics 79: 257-292.

Johnstone, K., and J. Bedard. 2001. Engagement planning, bid pricing, and client response: The effects of risk and market context in initial attest engagements. The Accounting Review 76: 199-220.

Kim, J., Y. Li, and L. Zhang. 2011. Corporate tax avoidance and stock price crash risk: Firm-level analysis. Journal of Financial Economics 100: 639-662.

Kim, O., and R. Verrecchia. 1994. Market liquidity and volume around earnings announcements. Journal of Accounting \& Economics 17: 41-67. 
Kothari, S. P., S. Shu, and P. Wysocki. 2009. Do managers withhold bad news? Journal of Accounting Research 47 (1): 241-276.

Krishnamurthy, S., J. Zhou, and N. Zhou. 2006. Auditor reputation, auditor independence, and the stockmarket impact of Andersen's indictment on its client firms. Contemporary Accounting Research 23 (2): 465-490.

Krishnan, G. 2005. Did Houston clients of Arthur Andersen recognize publicly available bad news in a timely fashion? Contemporary Accounting Research 22 (1): 165-204.

Krishnan, G., M. Pevzner, and P. Sengupta. 2012. How do auditors view managers' voluntary disclosure strategy? The effect of earnings guidance on audit fees. Journal of Accounting and Public Policy 31 (1): 492-515.

Lambert, R., C. Leuz, and R. Verrecchia. 2007. Accounting information, disclosure, and the cost of capital. Journal of Accounting Research 45 (2): 385-420.

Lang, M., and R. Lundholm. 1996. Corporate disclosure policies and analyst behavior. The Accounting Review 71 (4): 467-492.

Lang, M., and R. Lundholm. 2000. Voluntary disclosure and equity offerings: Reducing information asymmetry or hyping the stock? Contemporary Accounting Research 17 (4): 623-662.

Larker, D., and S. Richardson. 2004. Fees paid to audit firms, accrual choices, and corporate governance. Journal of Accounting Research 42 (3): 625-658.

Lyon, J., and M. Maher. 2005. The importance of business risk in setting audit fees: Evidence from cases of client misconduct. Journal of Accounting Research 43 (1): 133-151.

Morgan, J., and P. Stocken. 1998. The effects of business risk on audit pricing. Review of Accounting Studies 3 (4): 365-385.

O'Keefe, T., D. Simunic, and M. Stein. 1994. The production of audit services: Evidence from a major public accounting firm. Journal of Accounting Research 32 (2): 241-261.

Palmrose, Z. 1989. The relation of audit contract type to audit fees and hours. The Accounting Review 65 (3): 488-499.

Pevzner, M. 2007. Management Earnings Forecasts, Information Asymmetry, and Liquidity: An Empirical Investigation. Working paper, George Mason University.

Picconi, M., and J. K. Reynolds. 2013. Do Auditors Know More Than the Market? Working paper, The College of William \& Mary.

Pratt, J., and J. Stice. 1994. The effects of client characteristics on auditor litigation risk judgments, required audit evidence. The Accounting Review 69 (4): 639-656.

Public Company Accounting Oversight Board (PCAOB). 2010. Communications with Audit Committees. Auditing Standard No. 16. Available at: http://pcaobus.org/Standards/Auditing/Pages/Auditing Standard_16_Appendix_C.aspx\#_ftn1

Rosner, R., and A. Markelevich. 2011. Original and revised auditor fee data. Current Issues in Auditing 5 (1): A54-A69.

Seetharaman, A., F. Gul, and S. Lynn. 2002. Litigation risk and audit fees: Evidence from U.K. firms crosslisted on U.S. markets. Journal of Accounting \& Economics 33 (1): 91-115.

Sengupta, P. 1998. Corporate disclosure quality and the cost of debt. The Accounting Review 73 (4): 459474.

Simunic, D. 1980. The pricing of audit services: Theory and evidence. Journal of Accounting Research 18: 161-190.

Simunic, D., and M. Stein. 1996. The impact of litigation risk on audit pricing: A review of the economics and the evidence. Auditing: A Journal of Practice and Theory 15: 119-134.

Stanley, J. 2011. Is the audit fee disclosure a leading indicator of clients' business risk? Auditing: A Journal of Practice \& Theory 30 (3): 157-179.

Venkataraman, R., J. Weber, and M. Willenborg. 2008. Litigation risk, audit quality, and audit fees: Evidence from initial public offerings. The Accounting Review 83 (5): 1315-1345.

Welker, M. 1995. Disclosure policy, information asymmetry, and liquidity in equity markets. Contemporary Accounting Research 11 (2): 805-827. 
Whisenant S., S. Sankaraguruswamy, and K. Raghunandan. 2003. Evidence on the joint determination of audit and non-audit fees. Journal of Accounting Research 41 (4): 721-744.

Wilson, R. 2009. An examination of corporate tax shelter participations. The Accounting Review 84 (3): 969-999. 


\begin{tabular}{|c|c|}
\hline & $\begin{array}{c}\text { APPENDIX A } \\
\text { Definition of Variables }\end{array}$ \\
\hline Variable & Definition \\
\hline$\% \Delta$ Fees & Fiscal year percentage change in the audit fee (Audit Analytics, AUDIT_FEES). \\
\hline$\% \Delta$ Fees_Ind & $\begin{array}{l}\text { Industry median adjusted } \% \Delta F e e s \text { based on the annual two-digit SIC code (Audit } \\
\text { Analytics, AUDIT_FEES). }\end{array}$ \\
\hline CRASH & $\begin{array}{l}\text { Following Hutton et al. (2009), an indicator variable equal to } 1 \text { when } W_{i t}=\log (1 \\
\left.u_{i t}\right) \text { is more than } 3.09 \text { standard deviations below the company-specific annual } \\
\text { mean of } W_{i t} \text {, and } 0 \text { otherwise. The weekly residual stock return } u_{i t} \text { is estimated } \\
\text { follows: } \\
R_{i t}=a_{0}+a_{1} * R_{m, t-2}+a_{2} * R_{m, t-1}+a_{3} * R_{m, t}+a_{4} * R_{m, t+1}+a_{5} * R_{m, t+2}+u_{i t} \text {, where } \\
R_{i t} \text { is a company's total raw cumulative weekly stock return for week } t \text {; and } R_{m} \\
\text { is the cumulative value-weighted weekly stock return (CRSP, value-weighted } \\
\text { return). }\end{array}$ \\
\hline OPAQUE & 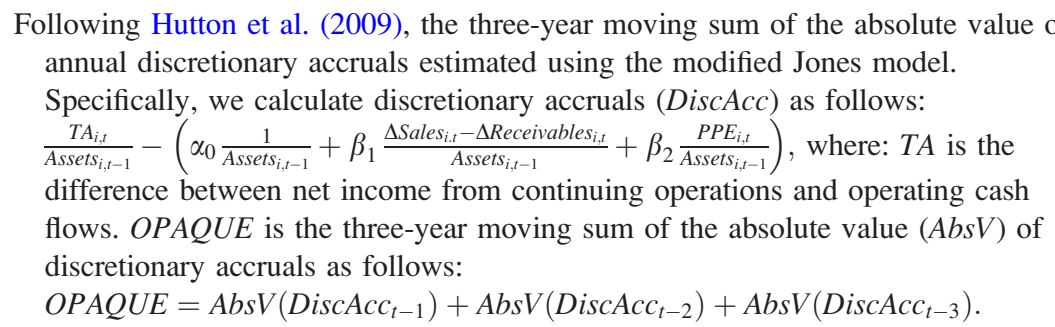 \\
\hline SHELTER & $\begin{array}{l}\text { Following Wilson (2009), SHELTER is defined as follows: } \\
\text { SHELTER }=4.86+5.20 * B T D+4.08 *|D A P|-1.41 * L E V+0.76 * A T+3.51 * \\
R O A 1+1.72 * F O R E I G N I N C O M E+2.43 * R \& D, \\
\text { where BTD is the total book-to-tax difference; }|D A P| \text { is the absolute value of } \\
\text { performance-matched discretionary accruals; } L E V \text { is long-term debt divided by } \\
\text { total assets; } A T \text { is log of total assets; ROAl is pre-tax earnings divided by total } \\
\text { assets; FOREIGN_INCOME is an indicator variable equal } 1 \text { if a firm reports } \\
\text { foreign income; R\&D is research and development expenses divided by total } \\
\text { assets. Data obtained from Compustat. }\end{array}$ \\
\hline
\end{tabular}

$R O E$

Income before extraordinary items divided by the book value of equity (Compustat, $\left.I B_{i t} / C E Q_{i t-1}\right)$.

SIZE

Log of the market value of equity (Compustat, LOG(PRCCF * CSHO)).

$M T B$

$L E V$

DTURN

NSKEW

Market value of equity divided by the book value of equity (Compustat, PRCCF * $\mathrm{CSHO} / \mathrm{CEQ}$ ).

Total liabilities divided by total assets (Compustat, LT and AT).

Following Chen, Hong, and Stein (2001), the monthly ratio of trading volume (VOL) to shares outstanding (SHROUT) minus the average of this ratio over the preceding 18 months.

Negative $\operatorname{SKEW}\left(W_{i t}\right)$, where $S K E W$ is the conditional skewness of a company's estimation period idiosyncratic weekly returns distribution. In particular: $N S K E W_{i t}=\left[n(n-1)^{3 / 2} \Sigma W_{i t}^{3}\right] /\left[(n-1)(n-2)\left(\Sigma W_{i t}^{2}\right)^{3 / 2}\right]$.

$W$ is defined above for the variable CRASH.

SIGMA

The fiscal year standard deviation of weekly residual returns $W$, where $W$ is defined above for the variable $C R A S H$.

(continued on next page) 


\section{APPENDIX A (continued)}

Variable

RET

$R O A$

FIRST404

$A C Q$

ISSUE

WEAK

$Q U A L$

$\% \triangle A S S E T$

$\% \triangle E A R N$

$\% \triangle F G N$

$\% \triangle M T B$

$\% \triangle L E V$

$\% \triangle S P E C$

$\% \triangle S E G M$

BIG5

$\% \triangle H E R F E N$

$\% \triangle C U R R E N T$ ASSETS

$\% \triangle C U R R E N T$ RATIO

$\% \triangle A R \_R A T I O$

$\% \triangle I N V$ RATIO

LOSS

\section{Definition}

The fiscal year average of weekly residual returns $W$, where $W$ is defined above for the variable $C R A S H$.

Income before extraordinary items divided by total assets (Compustat, IB and AT).

An indicator variable equal to 1 the first year a company received a Section 404 Internal Control opinion, and 0 otherwise (Audit Analytics, FYE_IC_OP).

An indicator variable equal to 1 if the company acquired a company in fiscal year $t$, and 0 otherwise (Compustat, AQS).

An indicator variable equal to 1 if the company issued stock in fiscal year $t$, and 0 otherwise; per SDC Platinum.

An indicator variable equal to 1 if the auditor found internal controls to be ineffective in fiscal year $t$, and 0 otherwise (Audit Analytics 404 Opinion file, IC_OP_TYPE $=$ "N").

An indicator variable equal to 1 if the audit report is adverse, qualified, or unqualified with explanatory language in year $t$, and 0 otherwise (Compustat, AUOP).

Fiscal year percentage change in assets (Compustat, AT).

Fiscal year percentage change in earnings (Compustat, IB).

Fiscal year percentage change in foreign income (Compustat, PIFO).

Fiscal year percentage change in the market-to-book ratio (Compustat, PRCC_F * $\mathrm{CSHO} / \mathrm{CE}$ ).

Fiscal year percentage change in liabilities (Compustat, LT).

Fiscal year percentage change in special items (Compustat, SPI).

Fiscal year percentage change in the number of reported segments (Compustat Segment Database, BUSSEG).

Indicator variable equal to 1 if the auditor is a Big $\mathrm{X}$ auditor, and 0 otherwise (Audit Analytics, AUDITOR_FKEY).

The Herfindahl-Hirschman index (HH) is calculated as the sum of the squares of the market shares for each firm within an industry (two-digit SIC) by year. We normalize the index so that it ranges from 0 to 1 by applying the following transformation:

Normalized $H H=\frac{H H-1 / N}{1-1 / N}$. This metric is then differenced and divided by the lagged index to produce the percentage change in the index year over year.

Percentage change in the ratio of current assets to total assets (Compustat, ACT and AT).

Percentage change in the current ratio (Compustat, ACT/LCT).

Percentage change in the ratio of accounts receivable to total assets (Compustat, RECT and AT).

Percentage change in the ratio of inventory to total assets (Compustat, INVT and AT).

An indicator variable equal 1 if a company reports negative net income before extraordinary items, and 0 otherwise (Compustat, IB). 
Copyright of Auditing: A Journal of Practice \& Theory is the property of American Accounting Association and its content may not be copied or emailed to multiple sites or posted to a listserv without the copyright holder's express written permission. However, users may print, download, or email articles for individual use. 